\title{
MODEL PENILAIAN KINERJA INSTRUKTUR SMK MIKAEL SURAKARTA: DALAM UPAYA MEMPERSIAPKAN LULUSAN SIAP KERJA
}

\author{
Tetty Setiawaty \\ Program Studi Pendidikan Teknik Bangunan \\ Jurusan Pendidikan Teknologi dan Kejuruan (PTK) FKIP UNDANA \\ tettysetiawaty@yahoo.com
}

\begin{abstract}
Abstrak : Penilaian kinerja adalah suatu sistem formal dan terstruktur yang mengukur, menilai pekerjaan karyawan dalam menjalankan tugas-tugasnya menggunakan standar kinerja (performance standard) yang sudah ditetapkan organisasi. Fokus penilaian kinerja adalah untuk mengetahui produktivitas seorang karyawan yang hasilnya dapat dipakai sebagai motivasi pada karyawan untuk bekerja lebih baik lagi. Jika ditemukan hasil penilaian kinerja yang buruk maka organisasi harus menindaklanjuti dengan cara memberikan pelatihan agar karyawan mampu meningkatkan kinerja yang diharapkan oleh organisasi. Penilaian kinerja harus memiliki validity, agreement, realism, dan objectivity, dimana hasil penilaiannya dapat bermanfaat bagi karyawan yang dinilai, bagi tim penilai dan bagi perusahaan.

Kata kunci: penilaian kerja, karyawan,instruktur dan lulusan siap kerja

Abstract: Performance appraisal is a formal and structured system of measuring and assessing employees' work performance using performance standards defined by organization. The focus of performance appraisal is to determine the employee productivity, whose results can later be used to motivation the employees to work better. If poor performance appraisal is found, the organization should follow up by providing training so that the employees are able to improve the performance as expected by the organization. Performance appraisals should have validity, agreement, realism, and objectivity, so that the result can be beneficial to the employee being assessed, the assessment team and the company.
\end{abstract}

Keywords: performance appraisal, employees, instructors and ready-to-work graduates

\section{PENDAHULUAN}

Salah satu permasalahan yang dihadapi pendidikan nasional saat ini adalah kompetensi lulusan SMK tidak sesuai dengan kebutuhan dunia usaha dan industri. Keadaan ini terlihat dari banyaknya pernyataan yang mengatakan mutu pendidikan khususnya SMK masih rendah (http://media.diknas.go.id/media/dokumen/ 4268.pdf). Ketidaksesuaian ini juga tergambar dari data Departemen Tenaga Kerja yang menunjukkan angka pengangguran terbuka berpendidikan menengah ke atas semakin meningkat. Bulan Februari 2010, diperkirakan jumlah angkatan kerja Indonesia mencapai 116 juta orang dibanding angkatan kerja Agustus 2009 sebesar 113,83 juta dan Februari 2009 sebesar 113,74 juta orang dibandingkan jumlah penduduk yang bekerja di Indonesia pada Februari 2010 mencapai 107,41 juta 
orang, Agustus 2009 yang sebesar 104,87 juta orang dan Februari 2009 sebesar 104,49 juta orang (http://www.bps.go.id). Secara rinci data tersebut dapat dilihat pada Tabel-1 berikut ini.

Tabel 1. Presentasi Pengangguran Terbuka Berdasarkan Pendidikan Tertinggi

\begin{tabular}{|c|l|c|c|c|c|c|}
\hline \multirow{2}{*}{ No } & \multicolumn{1}{|c|}{$\begin{array}{c}\text { Pendidikan Tertinggi yang } \\
\text { Ditamatkan }\end{array}$} & \multicolumn{2}{|c|}{2009} & \multicolumn{2}{|c|}{2010} & 2011 \\
\cline { 3 - 7 } & & Februari & $\begin{array}{c}\text { Agust } \\
\text { us }\end{array}$ & Februari & Agustus & Februari \\
\hline 1 & SD Ke Bawah SD & 4,70 & 4,57 & 4,51 & 3,78 & 3,71 \\
\hline 2 & Sekolah Menengah Pertama & 10,05 & 9,39 & 9,38 & 8,37 & 7,55 \\
\hline 3 & Sekolah Menengah Atas & 13,69 & 14,31 & 12,36 & 14,50 & 11,90 \\
\hline 4 & Sekolah Menengah Kejuruan & 14,80 & 17,26 & 15,69 & 14,59 & 13,81 \\
\hline 5 & Diploma I/II/III & 16,35 & 11,21 & 15,38 & 13,66 & 15,71 \\
\hline 6 & Universitas & 14,25 & 12,25 & 12,94 & 13,08 & 14,24 \\
\hline
\end{tabular}

Data: http://www.bps.go.id

Tabel di atas menunjukkan angkatan kerja lulusan SMK tidak tertampung sepenuhnya di lapangan kerja. Kesulitan dalam memperoleh pekerjaan disebabkan oleh program pendidikan yang diberikan tidak sesuai dengan kebutuhan yang ada di lapangan dan pola pembentukan SMK lebih berbasis pada kuantitas serta kurang memperhatikan kualitasnya. Gejala ini perlu segera diperbaiki agar lulusan SMK lebih bermutu dan berdaya saing (http:// www.setneg.go.id).

Permasalahan mendasar yang dihadapi SMK saat ini adalah adanya kesulitan besar dalam pencapaian kualitas lulusan SMK yang standardized, khususnya dalam bidang-bidang basic competencies. Banyak lulusan SMK yang tidak tertampung pada industri dan dunia kerja karena tidak mempunyai kompetensi sesuai dengan standar industri. Di samping itu, terdapat kesenjangan antara kompetensi yang dimiliki oleh lulusan SMK dengan kompetensi yang dibutuhkan dunia kerja (Junus dalam http://www.riaupos.com/v2/content /view/3109/30).

Belum tercapainya penguasaan kompetensi siswa SMK dijelaskan Sukardi TH. (2008:1), antara lain disebabkan oleh pembelajaran produktif yang dilaksanakan selama ini belum memenuhi kaidah-kaidah yang seharusnya ada, seperti kelengkapan fasilitas dan pengelolaannya, pelaksanaan pembelajaran efektif, sistem pendampingan siswa, dan semua yang berkaitan dengan pembelajaran produktif. Belum terpenuhinya fasilitas praktek dan pengelolaannya disebabkan 
oleh rendahnya penganggaran fasilitas dan peralatan praktek pendidikan SMK menyebabkan SMK kurang mengikuti perkembangan fasilitas dan peralatan kerja di industri. Belum terlaksananya pembelajaran efektif disebabkan juga oleh masih kurangnya guru praktek yang berkompeten mengajar praktik sesuai dengan kebutuhan lapangan kerja (http://www.acehforum.or.id/ pendidikan-kejuruan).

Kualitas SMK secara langsung merefleksi kualitas tenaga kerja Indonesia, oleh karena itu kualitas tenaga kerja harus dibangun untuk meningkatkan keunggulan kompetitif SDM. Rendahnya kualitas SDM Indonesia menyebabkan rendahnya daya saing Indonesia pada beberapa aspek kehidupan di tengah percaturan global saat ini. Hal ini disebabkan kurang relevansinya programprogram pembangunan pendidikan dalam menghadapi persoalan yang dihadapi oleh bangsa Indonesia dalam prospek kekinian dan masa depan (Tilaar, 2002:101). Kondisi ini apabila tidak segera diperbaiki akan menjadi ancaman bagi bangsa Indonesia dalam menghadapi Asian Free Trade Area (AFTA), North American Free Trade Agreement (NAFTA), Asian Pacific Economic Coorporation (APEC) pada tahun 2020 nanti. Oleh karena itu pendidikan nasional khususnya SMK perlu diperbaiki agar mampu melahirkan generasi yang memiliki keunggulan komparatif tinggi sehingga mampu bersaing ditingkat nasional maupun internasional.

Untuk mengatasi permasalahan SDM di Indonesia, pemerintah melalui Departemen Pendidikan Nasional menjalin kerja sama dengan pemerintah Jerman dalam program Indonesian German Institute (IGI). Terkait dengan program tersebut Pemerintah melalui Departemen Pendidikan Nasional, menunjuk lima institusi sebagai IGI Centre diantaranya adalah Akademi Teknik Mesin Industri (ATMI) Surakarta. Institusi yang dipilih wajib mengajukan suatu konsep pengembangan kualitas SDM dengan pola centre dan sister. Setiap centre harus memiliki kemampuan memberdayakan potensi yang dimilikinya untuk meningkatkan kualitas SDM melalui proses pelatihan yang berorientasi bisnis dan adanya transfer of technology (new technology). Sedangkan sister dipersiapkan dan dibina oleh centre dimana setiap centre harus memiliki minimal 2 sister, konsep tersebut harus dituangkan dalam business plan masing-masing centre dan 
terintegrasi dengan business plan masing masing sisternya (http://www. smkmikael.com /program_igi.shtml).

SMK Katolik St. Mikael Surakarta - selanjutnya disebut dengan SMK Mikael - sebagai sister dari ATMI Surakarta, adalah sekolah kejuruan dengan kompetensi keahlian teknik pemesinan (mechanical engineering). SMK Mikael memiliki visi menjadi pusat pendidikan teknik yang unggul dalam mengembangkan 4C yaitu competence, conscience, compassion dan commitment. Dengan fokus pendidikan mengembangkan teknologi unggulan di bidang mesin yang sudah dipertahankan sejak tahun 1962, lulusan SMK Mikael memiliki kompetensi dalam bidang teknik permesinan baik konvensional maupun CNC.

Indonesia saat ini menghadapi era globalisasi yang ditandai dengan perkembangan teknologi informasi yang bergerak sangat cepat, menyebabkan persaingan SDM sangat tinggi. Era globalisasi selain memberikan peluang dan tantangan juga memberikan ancaman bagi tenaga kerja yang tidak siap pakai dari berbagai sisi, karena terjadi persaingan SDM dari berbagai negara. Indonesia sebagai negara berkembang harus mampu menghadapi pasar bebas yang penuh tantangan dan persaingan. Untuk mengantisipasi era ini, SDM Indonesia dituntut memiliki keahlian tinggi dan keunggulan kompetitif agar mampu bersaing dalam memperebutkan lapangan kerja. SDM tangguh, unggul, berteknologi tinggi dan mampu berkompetensi sangat diperlukan dalam menghadapi era globalisasi.

Memasuki era globalisasi yang identik dengan era industri, masyarakat harus bisa survive karena masyarakat industri memiliki sifat antara lain: (1) mementingkan kualitas; (2) sangat mengutamakan persaingan untuk mencapai kualitas yang semakin meningkat; (3) munculnya nilai-nilai untuk mencapai yang terbaik (the search for excellence (Tilaar, 1998:78). Untuk mengantisipasi sifat masyarakat industri tersebut, SMK dituntut lebih produktif dan mampu menghasilkan lulusan siap pakai yang mampu bersaing dan menghadapi tantangan era globalisasi. Lulusan dengan kualitas tersebut dihasilkan oleh SMK yang berkualitas juga. 


\section{a. Pengertian penilaian kinerja}

Kinerja mengacu pada prestasi karyawan yang diukur berdasarkan standar atau kriteria yang ditetapkan perusahan. Berdasarkan dari persyaratan pekerjaan, Suprihanto menjelaskan kinerja karyawan adalah prestasi kerja seorang karyawan yang dilakukan pada periode tertentu dibandingkan dengan standar kinerja perusahaan yang sudah dirumuskan dan disepakati bersama-sama (Srimulyo,1999: 33). Pendapat senada dijelaskan Utomo, kinerja merupakan proses mengukur prestasi kerja pegawai berdasarkan peraturan yang telah ditetapkan, dengan cara membandingkan sasaran (hasil kerjanya) dengan persyaratan deskripsi pekerjaan yaitu standar pekerjaan yang telah ditetapkan selama periode tertentu. Standar kerja tersebut dapat dibuat baik secara kualitatif maupun kuantitatif (http://www. geocities.com). Lebih rinci Rivai \& Basri (2004: 14 ) menjelaskan kinerja adalah hasil seseorang secara keseluruhan selama periode tertentu dalam melaksanakan tugas, seperti standar hasil kerja, target atau sasaran atau kriteria yang telah ditentukan terlebih dahulu dan telah disepakati bersama

Pengertian kinerja atau prestasi kerja dijelaskan Maier sebagai kesuksesan seseorang dalam melaksanakan suatu pekerjaan, yang disebut oleh Lawler and Poter sebagai "succesfull role achievement" yang diperoleh karyawan dari pekerjaannya (As'ad, 2003:26). Untuk mendukung pencapaian kinerja yang sukses dibutuhkan lingkungan kerja menyenangkan yang mampu mendorong tingkat kinerja karyawan ke arah lebih produktif. Mengutip pendapat Bernardin dan Russel, Sulistiani menjelaskan kinerja merupakan catatan outcome yang dihasilkan dari fungsi karyawan atau kegiatan yang dilakukan selama periode waktu tertentu, berupa kombinasi dari kemampuan, usaha dan kesempatan yang dapat dinilai dari hasil kerja karyawan (Sulistiyani, 2003:223-224).

Dari pengertian kinerja di atas dapat disimpulkan, kinerja karyawan adalah prestasi kerja yang dicapai oleh karyawan dalam melaksanakan tugas atau pekerjaannya, sesuai dengan standar kriteria yang telah ditetapkan organisasi. Kinerja karyawan dapat ditingkatkan jika ada kesesuaian antara jenis pekerjaan, kemampuan karyawan dan lingkungan yang mendukung pekerjaannya. Kesesuaian tersebut mampu menghasilkan kepuasan kerja yang nantinya akan berpengaruh 
pada tingkat imbalan. Untuk mencapai kepuasan kerja maka dibutuhkan penilaian kinerja karyawan yang dilakukan secara terencana dan terstuktur dengan baik agar tujuan organisasi dapat tercapai.

Penilaian kinerja adalah suatu sistem formal dan terstruktur yang mengukur, menilai, dan mempengaruhi sifat-sifat yang berkaitan dengan pekerjaan, perilaku, dan hasil, termasuk tingkat ketidakhadiran. Fokus penilaian kinerja karyawan adalah untuk mengetahui produktivitas seorang karyawan, apakah ia bisa bekerja sama atau bekerja lebih efektif dimasa yang akan datang, sehingga karyawan, organisasi, dan masyarakat semuanya memperoleh manfaat (Schuler \& Jackson, 1996:3), Oleh Mondy dan Noe (1993:394), dijelaskan penilaian kinerja merupakan suatu sistem formal yang secara berkala digunakan untuk mengevaluasi kinerja individu dalam menjalankan tugas-tugasnya.

Penilaian kinerja yang baik mampu menciptakan gambaran yang tepat mengenai kinerja karyawan yang dinilai. Penilaian tidak hanya ditujukan untuk menilai dan memperbaiki kinerja yang buruk, namun juga mendorong para karyawan untuk bekerja lebih baik lagi. Berkaitan dengan hal ini, penilaian kinerja membutuhkan standar pengukuran, cara penilaian dan analisa data hasil pengukuran, dan tindak lanjut atas hasil pengukuran. Elemen utama dalam sistem penilaian kinerja menurut Werther dan Davis (1996:344) adalah standar kinerja (performance standard) dijadikan patokan pada kinerja yang akan diukur berhubungan erat dengan jenis pekerjaan dan kinerja yang diharapkan oleh perusahaan.

Davis menjelaskan, standar kinerja yang perlu diperhatikan adalah standar kinerja memiliki validity, agreement, realism, dan objectivity. Validity adalah keabsahan standar tersebut sesuai dengan jenis pekerjaan yang dinilai. Keabsahan yang dimaksud adalah standar tersebut memang benar-benar sesuai atau relevan dengan jenis pekerjaan yang akan dinilai. Agreement berarti persetujuan, yaitu standar penilaian yang digunakan telah disetujui dan diterima oleh semua karyawan yang akan dinilai kinerjanyan. Realism berarti standar penilaian tersebut bersifat realistis, dapat dicapai oleh para pegawai dan sesuai dengan kemampuan pegawai. Objectivity berarti standar tersebut bersifat obyektif, yaitu adil, mampu 
mencerminkan keadaan yang sebenarnya tanpa menambah atau mengurangi kenyataan dan sulit untuk dipengaruhi oleh subjektivitas penilai Werther dan Davis (1996:345-346).

Setelah melakukan penilaian kinerja, hasil penilaian harus disampaikan kepada karyawan yang dinilai dengan tujuan: (1) jika hasil penilaian kinerja positif, maka hasil penilaian tersebut dapat dijadikan motivasi agar karyawan tersebut lebih berprestasi lagi pada masa yang akan datang sehingga kesempatan meniti karier menjadi lebih terbuka; (2) jika hasil penilaian kinerja negatif, maka karyawan yang dinilai mengetahui kelemahannya dan berusaha sekuat tenaga untuk mengatasi kelemahannya tersebut; (3) jika karyawan merasa mendapat penilaian yang tidak obyektif, maka karyawan tersebut diberi kesempatan mengajukan keberatan sehingga pada akhirnya ia dapat memahami dan menerima hasil penilaian yang diperolehnya; (4) mengetahui peningkatan atau penurunan kinerja karyawan selama satu tahun; dan (5) sebagai bahan pertimbangan dalam melakukan promosi, alih tugas, mutasi karyawan atau memberhentikan karyawan.

\section{b. Proses Penyusunan Penilaian Kinerja}

Proses penyusunan penilaian kinerja menurut Mondy dan Noe (1993:398) terbagi dalam beberapa tahapan kegiatan yang ditunjukkan dalam gambar berikut.

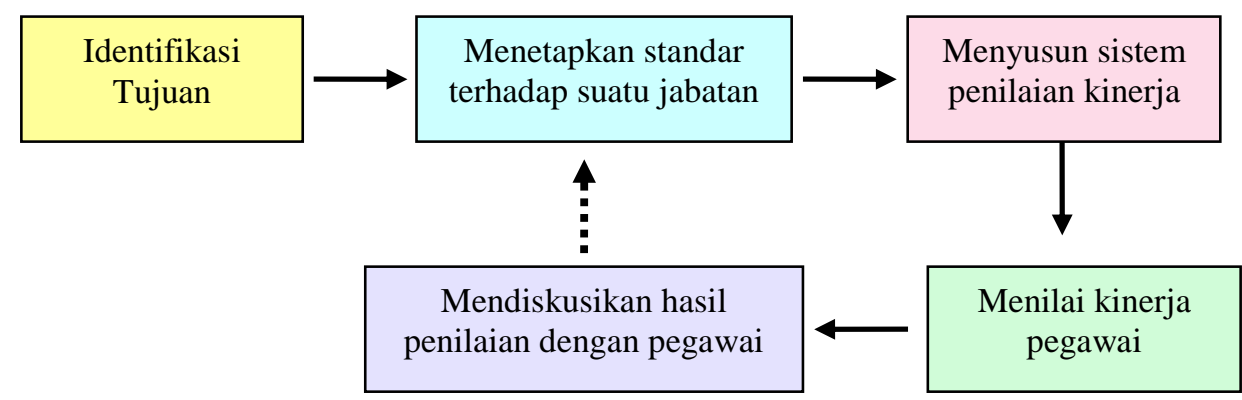

Gambar-1. Proses Penilaian Kinerja

(Mondy dan Noe, 1993:398)

Dari gambar di atas dapat dijelaskan, langkah pertama yang harus dilakukan dalam penilaian kinerja adalah mengidentifikasi tujuan penilaian. Identifikasi tujuan penilaian kinerja dilakukan dengan menentukan tujuan yang hendak dicapai suatu organisasi dalam menilai kinerja karyawannya. Identifikasi 
tujuan tersebut dapat mempermudah dalam menyusun dan menentukan bentuk penilaian kinerja masing-masing karyawannya. Langkah kedua, menetapkan standar terhadap suatu jabatan, yaitu menetapkan standar penilaian kinerja karyawan. Standar tersebut ditetapkan berdasarkan job description masing-masing jabatan yang sudah ditetapkan oleh organisasi, dimana dalam job description tertera tugas, wewenang dan tanggungjawab yang harus dilakukan oleh masingmasing jabatan.

Langkah ketiga adalah menyusun sistem penilaian kinerja yang dilakukan berdasarkan tujuan dan standar penilaian yang sudah ditetapkan. Sistem penilaian dapat dilakukan secara individu dan kelompok kerja atau dilakukan secara langsung maupun tidak langsung. Masing-masing organisasi melakukan sistem penilaian kinerja berbeda yang sangat bergantung pada tujuan penilaian yang akan dilakukan. Langkah keempat, adalah menilai kinerja karyawan. Penilaian dapat dilakukan oleh atasan langsung, oleh kelompok kerjanya masing-masing maupun oleh bawahnya. Hasil penilaian kemudian dianalisa oleh tim penilai atau dianalisa secara bersama-sama kelompok kerja.

Langkah kelima, mendiskusikan hasil penilaian kinerja karyawan. Hasil evaluasi kinerja karyawan dikomunikasikan secara langsung maupun tidak langsung. Komunikasi secara langsung dilakukan dengan cara mengumpulkan karyawan dan mendiskusikan hasil penilaian dan membandingkannya dengan hasil kinerja yang diharapkan organisasi. Dalam evaluasi tersebut pimpinan organisasi dapat meminta masukan atau saran-saran dari karyawan dan memberikan motivasi untuk perbaikan kinerja selanjutnya sedangkan komunikasi secara tidak langsung dilakukan dengan cara mengumumkan secara tertulis hasil penilaian kinerja karyawan di papan pengumuman tanpa melakukan pertemuan dengan karyawan dinilai kinerjanya. Hasil tahap terakhir ini dijadikan umpan balik untuk melihat apakah hasil penilaian kinerja karyawan sudah sesuai dengan hasil kinerja yang diharapkan oleh organisasi, jika diperlukan organisasi merevisi sistem penilaian kinerja atau merevisi job desription. Revisi diperlukan secara terus menerus menyasuaikan perkembangan teknologi dan informasi yang ada dimasyarakat 
khususnya dunia kerja membuat organisasi menjadi lebih dinamis, efektif dan efisien.

\section{c. Tujuan dan Manfaat Penilaian Kinerja}

Werther dan Davis (1996:342), menjelaskan penilaian kinerja karyawan memiliki beberapa tujuan bagi organisasi antara lain adalah sebagai:

performance improvement, compensation adjustment, placement decision, training and development needs, carrer planning and development, staffing process deficiencies, informational inaccuracies and job-design errors. equal employment opportunity, external challenges dan feedback. Secara lebih rinci Veithzal Rivai (2003:312) menjelaskan tujuan penilaian kinerja pada dasarnya adalah: (1) untuk mengetahui tingkat kinerja karyawan perusahaan selama ini; (2) sebagai pedoman untuk memberikan dan menaikkan gaji seperti: menaikkan gaji pokok, memberikan bonus, dll.; (3) mendorong pertanggung jawaban dari karyawan; (4) mengembangkan SDM yang dikelompokkan ke dalam bentuk kenaikan jabatan, mengikuti atau menambah jenis pelatihan yang harus dikuasai, mutasi ke bidang lain jika memiliki kinerja yang sangat memuaskan.

Manfaat penilaian kinerja dikelompokkan menjadi 3, yaitu: (1) manfaat bagi karyawan; (2) manfaat bagi penilai; dan (3) manfaat bagi perusahaan (Rivai \& Basri, 2004:62). Manfaat penilaian kinerja bagi karyawan yang dinilai dijelaskan, antara lain: adanya kejelasan standar kinerja yang diharapkan oleh perusahaan kepada masing-masing karyawannya; meningkatkan motivasi karyawan; meningkatkan kepuasan kerja karyawan; mengetahui kekuatan dan kelemahan masing-masing karyawan; membangun kekuatan masing-masing karyawan dan mengurangi kelemahan-kelemahan semaksimal mungkin; adanya pandangan yang jelas tentang kontek pekerjaan dan tanggungjawab masing-masing pekerjaan; dan meningkatkan hubungan harmonis dan aktif dengan atasan.

Manfaat penilaian kinerja bagi penilai (atasan, supervisor, manager, dll), adalah: mengukur dan mengevaluasi kecenderungan kinerja karyawan untuk perbaikan manajeman selanjutnya; mengembangkan sistem pengawasan; mengetahui kemampuan atasan dalam membina karyawannya bekerja; meningkatkan kepuasan kerja baik terhadap karyawan dan manajer perusahaan; lebih memahami kondisi karyawannya dan merencanakan pelatihan-pelatihan 
yang diperlukan oleh masing-masing karyawan; melakukan mutasi karyawan sesuai dengan kinerja masing-masing; dan merencanaan target yang hendak dicapai pada penilaian kinerja karyawan yang akan datang.

Manfaat penilaian kinerja karyawan bagi perusahaan antara lain adalah: sebagai evaluasi untuk mengidentifikasi penyebab kekurangan, baik yang berhubungan dengan sistem perusahaan maupun berhubungan dengan karyawan itu sendiri; meningkatkan tugas, wewenang dan tanggungjawab masing-masing karyawan; meningkatkan motivasi karyawan secara keseluruhan; mengetahui lebih jelas permasalahan yang dihadapi karyawan dan jenis pelatihan yang dibutuhkan karyawan; dan meningkatkan budaya kerja dan kinerja perusahaan.

\section{METODE}

\section{a. Jenis Penelitian}

Pendekatan penelitian yang digunakan adalah penelitian kualitatif, menggunakan metode studi kasus. Pengumpulan data penelitian menggunakan wawancara mendalam (in depth interview), pengamatan partisipatif (participant observation) dan dokumentasi. Wawancara mendalam diartikan sebagai proses bertemu muka antara peneliti dan responden yang direncanakan untuk mendapatkan informasi yang diperlukan. Wawancara didesain untuk mengetahui persepsi, motivasi, sikap, tingkah laku dari orang-orang yang diwawancarai. Ciriciri wawancara mendalam dijelaskan Denzin (2009:633) adalah: melibatkan individual, bertatap muka dan menggunakan percakapan verbal, kadang menggunakan kuesioner sebagai pedoman wawancara atau model terstruktur, dan menggunakan telepon misalnya untuk survey. Pengamatan partisipasi adalah metode mengumpulkan data yang dilakukan secara alami melalui pengamatan langsung di lapangan atau ikut mengambil bagian pada setiap kegiatan atau aktivitas dari orang-orang yang diamati. Pengamatan partisipasi sangat penting dilakukan karena dapat meningkatkan kualitas data yang diperoleh selama di lapangan, dapat meningkatkan kualitas interprestasi data melalui pengumpulan data dan analisis data, dan mendorong perumusan formulasi baru melalui pertanyaan penelitian atau hipotesis yang didasari oleh hasil pengamatan di lapangan. Secara 
sederhana Borg and Gall (1983:490), menjelaskan participant observation is well suited for the investigation of many educational problems.

\section{b. Tempat dan Waktu Penelitian}

Penelitian ini dilakukan SMK Mikael dengan kompetensi keahlian teknik pemesinan (mechanical engineering). Waktu penelitian dilaksanakan selama 3 bulan, dengan rincian pelaksanaan penelitian di SMK Mikael pada 2 Maret s.d. 24 Mei 2010 dilanjutkan Januari 2011.

\section{c. Sumber Data}

Subjek penelitian atau responden penelitian ini adalah semua personil sekolah, seperti: kepala sekolah, wakil kepala sekolah, guru/instruktur, tenaga kependidikan, siswa, ditambah Wakil Manajemen Mutu (WMM), Human Resources Development (HRD), alumni, industri pasangan, dan petugas kebersihan (house keeping). Sumber data diambil menggunakan teknik purposive sampling. Objek penelitian dalam tulisan ini adalah pendidik khususnya instruktur yang dikelompokkan mejadi dua yaitu instruktur bengkel mekanik dan instruktur gambar.

\section{d. Teknik dan Instrumen Pengambilan Data}

Teknik pengambillan data penelitian dilakukan dengan cara wawancara mendalam, pengamatan partisipasi dan dokumentasi. Wawancara mendalam yang dilakukan adalah wawancara bebas (free interview), dengan mengembangkan pertanyaan dari pedoman wawancara yang sudah dibuat sebelumnya. Wawancara dilakukan menggunakan jadwal yang sudah disepakati bersama. Pengamatan partisipasi pasif dilakukan dengan mengamati secara langsung semua kegiatan yang dilakukan masing-masing sekolah. Dokumentasi dilakukan dengan mengamati semua dokumen-dokumen sekolah yang diperlukan untuk mendukung hasil wawancara dan partisipasi. Instrumen penelitian yang digunakan pada penelitian (human instrument) ini adalah peneliti sendiri. Alasan menggunakan peneliti sebagai instrumen penelitian adalah rancangan penelitian kualitatif studi 
kasus yang dibuat masih bersifat sementara dan akan berkembang setelah peneliti memasuki objek penelitian.

\section{f. Keabsahan dan Analisis Data}

Keabsahan data dilakukan dengan diuji kredibilitas data. Uji kredibilitas data dilakukan dengan cara: perpanjangan pengamatan, meningkatkan ketekunan, trianggulasi data, analisis kasus negatif, dan member check dengan mendiskusikan hasil penelitian dengan sumber-sumber data yang telah memberikan data. Analisis data menggunakan analisis data model interaktif dari Miles dan Huberman. Secara rinci dapat dilihat pada Gambar-2 berikut ini.

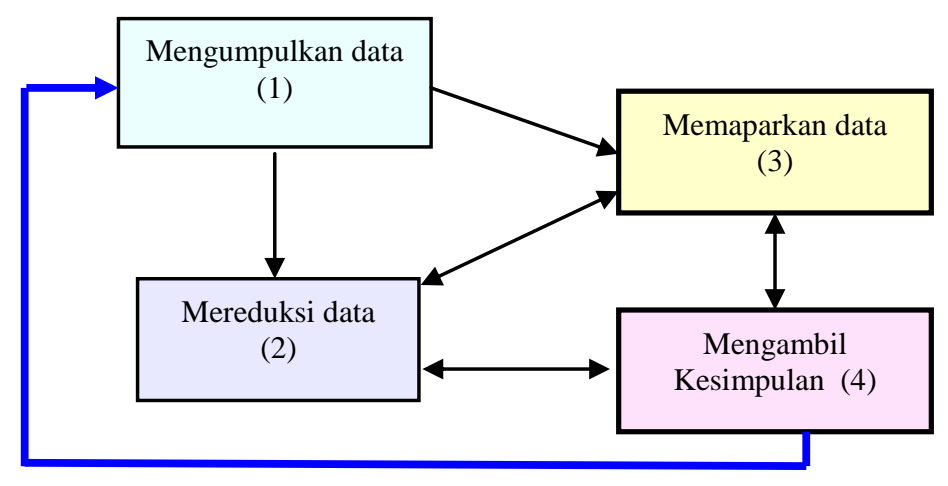

Gambar-2. Komponen-komponen Analisis Data Model Interaktif (Miles dan Huberman, 2007:20).

\section{HASIL}

SMK Mikael memiliki 43 orang pendidik yang terdiri dari 15 guru teori dan 28 instruktur. Jumlah guru normatif 5 orang dan 10 orang guru adaptif. Instruktur dikelompokkan menjadi 23 instruktur mekanik dan 5 instruktur gambar. Instruktur di SMK Mikael adalah karyawan ATMI yang diperbantukan mengajar praktek di SMK Mikael. Tugas utama instruktur adalah membimbing praktek siswa, dan sebagai karyawan ATMI, instruktur ditugaskan untuk tetap berproduksi di luar jam mengajar praktek. Tujuan berproduksi adalah selain mengerjakan barang-barang pesanan dari ATMI, IGI, industri dan masyarakat luar, keterampilan (skills) instruktur tetap terjaga dengan baik. Instruktur mengetahui jenis pekerjaan yang 
banyak dipesan oleh masyarakat, perkembangan teknologi bahan dan cara kerja yang semuanya akan ditularkan kembali kepada siswanya.

Instruktur bekerja pada hari Senin sampai Jumat dari pukul 07.00 sampai 16.00. Jika instruktur bekerja pada shift pagi atau siang maka jam kerja mengikuti jam shift masing-masing kelas. Kelas X memiliki 2 shift yaitu jam $06.55-12.00$ WIB (shift pagi) dan jam 12.55 - 18.00 WIB (shift siang). Kelas XI dan XII memiliki dua shift yaitu jam 06.55 - 14.45 WIB (shift pagi) dan jam 14.25 - 22.00 WIB (shift sore). Instruktur tidak libur saat siswa libur semester maupun kenaikan kelas karena harus tetap berproduksi, tetapi mendapat hak cuti selama 12 hari kerja selama 1 tahun.

Instruktur yang bekerja di luar jam efektif pembelajaran, seperti hari Sabtu, Minggu atau hari libur, dihitung lembur dan dibayar sesuai dengan aturan lembur yang diterapkan ATMI. Kenaikan pangkat atau golongan instruktur dilakukan setiap empat tahun sekali dan tidak diterapkan kenaikan gaji berkala. Penggajian untuk instruktur mengikuti penggajian yang diterapkan oleh ATMI, di luar gaji pokok dan kesejahteraan, ATMI membayar jam lembur instruktur setiap bulannya.

\section{PEMBAHASAN}

Penilaian kinerja pendidik ditujukan untuk pembinaan, pengembangan atau pemberhentian karir pendidik dilakukan langsung oleh Wakasek IV. Penilaian dimulai dari persiapan pembelajaran sampai evaluasi. Persiapan pembelajaran dimulai dengan membuat bahan ajar seperti: silabus, lesson plan, rencana pembelajaran selama satu tahun ajaran dan membuat analisis urutan logis mata pelajaran. Semua bahan ajar tersebut harus lulus verifikasi Wakasek IV sebelum diterapkan dalam pembelajaran. Penilaian kinerja instruktur dilakukan dengan cara:

\section{1) Melihat nilai praktek dan ketuntasan praktek siswa.}

Siswa yang memiliki nilai praktek di bawah kriteria ketuntasan minimal (KKM) yaitu nilai 7 untuk praktek atau siswa yang kurang tuntas pada suatu section, instruktur section akan dipanggil untuk mempertanggungjawabkan kinerjanya. Penilaian kinerja instruktur dengan cara ini sangat baik dilakukan karena instruktur yang berhasil membimbing siswa praktek akan dapat dilihat dari 
nilai praktek siswa. Instruktur yang memiliki kinerja yang kurang baik akan dibimbing oleh koordinator kelas masing-masing dan pembinaan terakhir dilakukan oleh Kepala Bengkel. Masing-masing koordinator kelas melakukan koordinasi dengan Kepala bengkel untuk mengevaluasi kinerja masing-masing instruktur setiap putaran praktek yang hasil kinerja masing-masing instruktur dapat dilihat dari daftar nilai dan daftar ketuntasan praktek atau hasil praktek siswa.

\section{2) Menilai kinerja instruktur dilakukan dengan cara menilai kinerja diri} sendiri bersama kelompok kerja dan menilai diri sendiri bersama atasan.

Penilaian kinerja instruktur dengan cara tersebut dilakukan secara terbuka dan hasil penilaian kemudian dibahas bersama-sama sebagai evaluasi kinerja selama satu semester dan satu tahunnya. Penilaian dilakukan dengan cara mengisi kolom penilaian yang sudah dibuat oleh Wakasek IV dan kepala sekolah dan masing-masing koordinator kelas.

Menilai diri sendiri dikelompokkan dalam beberapa kategori, yaitu:

(1) Pemenuhan tuntutan kerja, terdiri dari: pendampingan dan pelayanan dalam mengajar; metode dan cara penerapan mengajar; penyampaian dan penyajian materi ajar: pemenuhan target mengajar; pemenuhan kualitas produk (jasa produksi); dan pemenuhan waktu serah yang disepakati (jasa produksi).

(2) Perilaku selama bekerja, terdiri dari penilaian: kepatuhan dan ketaatan terhadap pimpinan; dapat dipercaya (ketidaktergantungan dari pengawasan; tertib administrasi; tertib sarana dan prasarana kerja; tertib pelaporan ketidaksesuaian; dan tertib perbaikan cara dan sarana kerja.

(3) Kehadiran, terdiri dari penilaian: kehadiran setahun; keterlanbatan; dan interusi.

(4) Sikap dalam bekerja, terdiri dari penilaian: semangat/antusiasme dalam melaksanakan pekerjaan; kepedulian pada orang lain; kerja sama; sikap mau memperbaiki diri; daya juang; peduli pada kebersihan lingkungan; dan terbuka terhadap saran dan kritik. Proses penilaian dilakukan dengan cara: masing-masing instruktur menilai kinerja dirinya sendiri dan dinilai oleh 
kelompok kerjanya. Secara rinci penilaian diri senriri bersama kelompok kerja dapat dilihat pada Lampiran-1 dan Lampiran-2.

\section{3) Pemberian Motivasi}

Instruktur yang memiliki kinerja sangat baik diberi penghargaan dengan diberikan kenaikan gaji sebesar 5 - 20\% dan diberikan pedang emas secara bergilir setiap tahun. Selain mendapatkan penghargaan tersebut instruktur berprestasi diberi kesempatan magang di industri pemesinan di Jerman dan Swiss selama 1 tahun dengan biaya dari yayasan. Tanda jasa diberikan kepada pegawai yang sudah berbakti pada yayasan Karya Bakti Surakarta selama 25 tahun. Tanda jasa diberikan dalam bentuk cincin emas 22 karat seberat 10 garam bertanda Centre of Technical Education (CTE). Pemberian motivasi tersebut diberikan oleh yayasan bertujuan memotivasi kinerja karyawannya.

\section{KESIMPULAN}

Keberadaan instruktur sebagai salah satu kunci keberhasilan di SMK Mikael Surakarta dituntut memiliki kompetensi pedagogik dan kompetensi akademik sesuai dengan sectionnya masing-masing. SMK Mikael Surakarta memiliki instruktur dengan kompetensi tinggi pada bidangnya dan melaksanakan pekerjaannya secara profesional, fokus pada pengembangan profesional dan keterampilan pendidik, disiplin dalam mengajar dan menilai hasil kerja siswa. Sekolah menerapkan persyaratan khusus dan sangat ketat pada rekrutmen pendidik, mewajibkan semua instruktur memiliki pengalaman bekerja di industri, dan menilai kinerja pendidik secara terus menerus dengan melihat prestasi dan hasil kerja siswa.

Penilaian kinerja pendidik dilakukan dengan menilai kerajinan, ketekunan dan hasil evaluasi belajar siswa. Penilaian kinerja bertujuan untuk pembinaan, pengembangan, pemindahan tugas, dll., dilakukan langsung oleh Wakasek yang menjadi atas langsung pendidik dan Kepala Sekolah. Pemberian motivasi bagi pendidik yang memiliki prestasi kerja dilakukan dengan memberikan menaikkan persentasi gaji pendidik dan membantu dana pendidikan anak-anak pendidik yang akan melanjutkan sekolah ke jenjang yang lebih tinggi. Melakukan evalusi kinerja 
pendidik secara terus menerus. Evaluasi bertujuan meningkatkan kinerja pendidik yang tujuan akhirnya adalah meningkatkan kompetensi keahlian siswa.

\section{DAFTAR PUSTAKA}

As'ad, Muhamad. 2003. Psikologi Industri. Yogyakarta: Libery.

Alma, Buchari. 2008. Guru Profesional: Menguasai Metode dan Terampil Mengajar. Bandung: Alfabeta.

BPS. 2011. Survei Angkatan Kerja Nasional 2009-2011. Diambil pada tanggal 10 November 2010, dari (http://www.bps.go.id).

Brinkerhoff, Robert \& Dressler Dennis. 1990. Productivity Measurement: A guide for Managers and Evaluator. Newbury Park, California: SAGE Publications, Inc.

Clayton, B., Fisher, T and Hughes, E. 2005. Sustaining the Skill Base of Technical and Further Education Institutes: TAFE managers' Perspectives. A National Vocational and Training Research and Evaluation Program Report. Adelaide: National Centre for Vocational Education Research (NCVER) Publications.

Denzin, N.K. \& Lincoln, Y.S. 2009. Handbook of Qualitative Research. ( $1^{\text {St }}$ ed.). New Delhi: Sage Publication India Pvt. Ltd.

Fakhri, Zahrial. 2007. Pendidikan Kejuruan di Indonesia. Makalah. Diambil pada 25 Oktober 2009, dari (http://www.acehforum.or.id/pendidikan-kejuruandi-t9554.html)

Fry, H., Katteridge, S., \& Marshall S. 2003. A Handbook for Teaching \& Learning in Higher Education. Enhancing Academic Practice. London: Kegan.

Gasskov, Vladimir. 2005. Managing Vocational Training System: A Handbook for Senior Administrators. Geneva: International Labour Office.

Junus, Nurpit. 2008. Peradigma Baru Pengelolaan SMK. Diambil pada tanggal 28 November 2008, dari: (http://www.riaupos.com/v2/content/view/3109/30/.)

Mondy, R.W., Noe, R.M., Premeaux, S.R.,(1993), Human Resource Management (5rd ed.), Massachusetts, Allyn and Bacon.

Noor, Khairul BM. 2008. Case Study: A Strategic Research Methodology. American Journal of Applied Sciences 5 (11): 1602-1604, 2008. ISSN 1546-9239. Science Publications. Diambil pada tanggal 27 Mei 2009, dari: (http://www.scribd.com/doc/54263058/Noor-2008-Case-Study-StrategicReseach-Meth.) 
Rivai, Veithzal dan Basri. 2005. Performance Appraisal: Sistem Yang Tepat Untuk Menilai Kinerja Karyawan Dan Meningkatkan Daya Saing Perusahaan. Jakarta: Rajagrafindo Persada.

Schuler, Randal S. dan Jackson, Susan E, 1996, Manajemen Sumber Daya Manusia Menghadapi Abad ke 21, Jilid 2, Edisi Keenam, Penerbit Erlangga, Jakarta.

Sekretariat Negara Republik Indonesia. 2010. Keharmonisan Tenaga Kerja dan Pendidikan di Indonesia. Diambil pada tanggal 29 Januari 2010, dari: (http://www.setneg.go.id). Jakarta: Sekretariat Negara Republik Indonesia.

Simamora, Henry, 1997. Manajemen Sumber Daya Manusia. Edisi Kedua.STIE : YKPN

SMK Katolik St. Mikael. 2009. SMK St. Mikael Surakarta sebagai Sekolah Unggulan. Diambil pada tanggal 14 Januari 2010, dari: (http://www.smkmikael.com)

SMK Katolik St. Mikael. 2009. Program Indonesian German Institute (IGI) Diambil pada tanggal 14 Januari 2010, dari: (http://www.smkmikael.com/ program_igi.shtml)

Sukardi, M.S. 2006. Penelitian Kualitatif-Naturalistik Dalam Pendidikan. Yogyakarta: Usaha Keluarga.

Sukardi, TH. 2008. Pengembangan Model Bengkel Kerja Praktek Sekolah Menengah Kejuruan. Disertasi. Yogyakarya: Universitas Negeri Yogyakarta.

Sulistiyani, Ambar T. dan Rosidah.2003. Manajemen Sumber Daya Manusia. Graha Ilmu: Yogyakarta

Syafrizal, M. (2007. Mutu Kinerja Sekolah Menenah Kejuruan. Diambil pada tanggal 20 November 2008, dari: (http://media.diknas.go.id/media).

Tika, P. 2006. Budaya Organisasi Dan Peningkatan Kinerja Perusahaan. PT Bumi Aksara. Jakarta

Werther, Wlillian B, dan Davis, Keith. 2003, Human Resources and Personnel Management, 5th Edition, McGraw-Hill, Inc, New York.

Tilaar, HAR, 1998. Manajemen Pendidikan Nasional: Kajian Pendidikan Masa Depan. Bandung: Remaja Rosdakarya

Tilaar, HAR. 2002. Pendidikan Untuk Masyarakat Indonesia Baru: 70 Tahun Prof. Dr. H.A.R. Tilaar, M.Sc.Ed. Jakarta:Grasindo

Timple, A. Dale. 192. Seri Manajemen Sumber Daya Manusia: Kinerja. Jakarta: PT Elex Media Komputindo

Werther, Wlillian B, dan Keith Davis, 2003, Human Resources and Personnel Management, 5th Edition, McGraw-Hill, Inc, New York. 